\title{
PEMBERDAYAAN MASYARAKAT \\ MELALUI PELATIHAN SPIRITUAL TOUR GUIDE DI KAWASAN PURA PULAKI
}

\author{
oleh, \\ Putu Eka Dambayana Suputra \\ Fakultas Bahasa dan Seni, \\ Universitas Pendidikan Ganesha
}

\begin{abstract}
ABSTRAK
Keberadaan masyarakat lokal di sekitar kawasan wisata merupakan potensi yang penting diberdayakan guna perbaikan taraf hidup masyarakat di sekitar kawasan dan meningkatkan kesadaran masyarakat setempat akan pentingnya menjaga kawasan wisata di daerah mereka. Pergeseran tujuan wisata dari wisata hiburan ke wisata spiritual membuka peluang besar bagi masyarakat lokal di Bali pada khususnya untuk menekuni usaha jasa pramuwisata spiritual atau Spiritual Tour Guide. Oleh karena hal tersebut, program Pemberdayaan Masyarakat melalui Pelatihan Spiritual Tour Guide di kawasan Pura Pulaki dijalankan. Mitra adalah pemuda desa Banyupoh di Kecamatan Gerokgak, kabupaten Buleleng, Bali. Metode yang digunakan adalah melalui simulasi (training and simulation = TS). Secara umum program berlangsung dengan baik, namun pengetahuan dan keterampilan mitra masih tergolong cukup.
\end{abstract}

Kata-kata kunci: pramuwisata, spiritual tour guide

\begin{abstract}
The existence of the local human resource in line with tourism in some tourist destinations is an important thing to be improved for a betterment of their economic life and improvement of awareness towards an attempt to preserve the destination itself. In addition, the change of tourist interest from tourism for entertainment to tourism for spiritual experience has opened a great opportunity for local people to be involved in a work of so called Spiritual Tour Guide. Because of these two concerns, a program of empowering local people through a workshop on Spiritual Tour Guide in Pulaki temple area (Pemberdayaan Masyarakat melalui Pelatihan Spiritual Tour Guide di kawasan Pura Pulaki) was held. The participants were young people of Banyupoh village of Gerokgak district, Buleleng regency, Bali. Within the workshop, simulation was used as the method. Generally, the program was held successfully, although the participants' knowledge and skills still need to be improved.
\end{abstract}

Keywords: tourism, guide, spiritual tour guide. 


\section{Pendahuluan}

Usaha wisata di kabupaten Buleleng berkembang dengan cukup baik. Terbukti dengan adanya kunjungan wisatawan lokal dan manca negara ke beberapa objek wisata, restauran, dan hotel-hotel yang ada di beberapa kawasan wisata di Buleleng setiap bulan Juli sampai Desember tiap tahunnya. Mereka datang dalam jumlah besar, baik individu maupun kelompok, terutama pada hari-hari besar atau libur dan perayaan-perayaan tertentu dengan motivasi berwisata yang beragam.

Terkait dengan motivasi berwisata, telah terjadi pergeseran dari wisata refreshing atau hiburan menjadi wisata budaya dan bahkan wisata spiritual. Hal ini tidak bisa dipungkiri karena semakin banyak wisatawan yang mulai bosan dengan paket-paket wisata yang hanya menawarkan hingar-bingar, kemewahan, dan keindahan. Mereka, dewasa ini, cenderung mulai menikmati tawaran wisata yang menawarkan jenis-jenis terapi, meditasi, kunjungan ke situs-situs sejarah/purbakala, kunjungan ke daerahdaerah tempat penduduk asli bermukim, menyaksikan upacara-upacara keagamaan, kunjungan ke tempat-tempat suci guna memperoleh informasi yang akurat dan tepat, mempelajari sejarah dan budaya, memperoleh ketenangan, kenyamanan, dan keharmonisan pikiran, jiwa, dan raga. Wisata semacam ini dikenal dengan istilah Wisata Spiritual atau Spiritual Tour Guide yang bisa juga dilakukan di Buleleng.

Namun sangat disayangkan, masyarakat lokal asli yang tahu seluk beluk tentang tempat tujuan wisata tertentu terkendala dalam memberikan informasi yang benar, lengkap, dan tepat kepada wisatawan. Di samping itu pula, mereka mengalami kendala berbahasa asing, utamanya Bahasa Inggris, ketika memandu wisman (wisatawan manca negara). Sering terjadi kesalahpahaman antara mereka dan wisman. Keterbatasan informasi yang mereka miliki karena terbatasnya pengetahuan mereka. Hal ini sangat terlihat ketika wisman mulai bertanya tentang mengapa dan bagaimana (asal-usul, fungsi, dan kegunaan) tempat itu di daerah mereka. Mereka lebih sering menggunakan common sense mereka dalam memberikan keterangan terkait pertanyaan tersebut. Hal ini berdampak pada ketidakpuasan yang dirasakan oleh para wisatawan. Sebagai akibatnya, uang jasa yang mereka terima dalam bentuk tip dirasa tidak sebanding dengan jerih payah mereka dalam melayani wisatawan. 
Merujuk pada pentingnya pengembangan jasa pariwisata di wilayah kabupaten Buleleng, khususnya di desa Banyupoh, kecamatan Gerokgak; pentingnya pemberdayaan masyarakat lokal pada situs-situs pura yang menjadi objek wisata spiritual di masa kini dan pada masa mendatang; dan keterbatasan pengetahuan, pengalaman, keterampilan pemanduan wisata, serta keterbatasan keterampilan berbahasa asing masyarakat lokal di sekitar lokasi objek wisata spiritual, program Pengabdian Pada Masyarakat bertajuk Pemberdayaan Masyarakat Melalui Pelatihan Spiritual Tour Guide di Kawasan Pura Pulaki dilaksanakan. Program serupa juga telah dilaksanakan pada tahun 2010 dan 2011 dengan tujuan yang sama.

Pada periode pertama di tahun 2010, pelatihan diberikan terkait dengan Spiritual Tour Guiding (Pemanduan Wisata Spiritual) tentang pura-pura umum. Pada saat itu, mahasiswa Jurusan Agama Hindu STKIP Agama Hindu Singaraja di Kabupaten Buleleng memperoleh pelatihan guiding dan keterampilan berbahasa Inggris dalam menjelaskan pura-pura umum. Mereka juga mendiskusikan landasan filosofis dan emperis yang terkandung dalam memberikan penjelasan terkait keberadaan masingmasing pura bersama-sama narasumber terkait. Selanjutnya mereka menterjemahkan penjelasan dimaksud, mengemasnya secara singkat dan padat, serta melatihkannnya dalam bentuk simulasi (Nitiasih dkk, 2010).

Merespon permintaan mahasiswa dan pihak pengelola STKIP Singaraja, pada periode ke dua tahun 2011, mahasiswa kembali memperoleh pelatihan spiritual tour guide dengan tema Upakaral banten. Pada saat pelatihan, mahasiswa disertai narasumber terkait berdiskusi secara aktif dalam mengupas makna, fungsi, dan tata cara upakara/ banten sebagai sarana upacara. Mereka juga membuat berbagai jenis banten yang menjadi dasar upakara yang lebih besar. Setelah itu, mereka menterjemahkan segala penjelasan tentang upakara dimaksud ke dalam Bahasa Inggris serta mencoba menjelaskan makna, fungsi, dan tata cara pembuatan upakara/banten dimaksud pada tahap simulasi (Suputra dkk., 2011).

Tiga bulan setelah pelaksanaan program P2M di STKIP Agama Hindu Singaraja, mahasiswa asal desa Banyupoh menghubungi salah satu tim kami secara personal dan mengajukan permintaan untuk mengadakan pelatihan serupa di desa mereka. Terkait kebermanfaatan yang mereka rasakan setelah pelaksanaan program P2M dimaksud dan 
keinginan mahasiswa untuk memberikan pengetahuan dan keterampilan serupa pada generasi muda yang tergabung di dalam Sekaha Teruna Teruni desa Banyupoh, maka kami bersama-sama mahasiswa dan anggota sekeha merancang sebuah program pelatihan dan pendampingan yang kemudian menjadi program Pengabdian Kepada Masyarakat. Program ini juga melibatkan keikutsertaan para pemandu wisata lokal di kawasan Pura Pulaki, khususnya mereka yang telah menjadi pemandu wisata secara otodidak di beberapa kawasan Pura Pulaki guna memantapkan pengetahuan dan keterampilan mereka sekaligus berbagi pengalaman pemanduan wisata kepada rekanrekan yang berkeinginan menekuni jasa pemanduan wisata spiritual atau Spiritual Tour Guide.

Secara umum terdapat beberapa permasalahan yang muncul di lapangan meliputi: (1) Mitra memiliki keterbatasan jenis usaha yang bisa dikembangkan di wilayah tersebut. Perdagangan, nelayan atau perburuhan merupakan jenis usaha yang bisa dilakukan oleh masyarakat setempat dengan rata-rata pendapatan yang sangat minim, (2) Mitra memerlukan alternatif usaha guna memperbaiki taraf hidup mereka, (3) Mitra tidak memiliki pengetahuan dan pedoman informasi memadai dan praktis tentang kawasan yang berpotensi pariwisata di wilayah mereka, (4) Mitra memiliki keterbatasan keterampilan pemandu wisata (guiding), (5) Mitra memiliki keterbatasan keterampilan berbahasa asing aktif dan komunikatif dalam memberikan informasi kepada para wisman, (6) Pemandu wisata spiritual yang memadai dari segi bobot pengetahuan atau informasi yang benar dan tepat masih sangat kurang.

\section{Metode Pelaksanaan Pengabdian}

Bentuk aktivitas menggunakan strategi pelatihan dan pendampingan dengan simulasi (training and simulation = TS). Tahapan-tahapan aktivitas secara umum yaitu: penyemaian informasi (encoding), pengintegrasian informasi menjadi suatu pemahaman (decoding), perekaman informasi (storing), pelatihan informasi melalui simulasi (rehearsal), dan pembelajaran informasi (learning). Strategi ini dilakukan agar mitra langsung melatihkan dan merasakan pengalaman pemanduan secara optimal. Pemberian penjelasan dasar-dasar pemanduan dan teori terkait serta keterampilan Bahasa Inggris diberikan sebesar 30\%. Sisanya (70\%) digunakan untuk latihan dan simulasi. 
Rancangan metode pelaksanaan kegiatan ini disusun berdasarkan pemetaan permasalahan yang ada di lapangan dan alternatif solusi yang dirancang bersama-sama pihak sekaha teruna- teruni dan kepala desa beserta jajarannya. Pemetaan permasalahan dan alternatif solusi sebagai berikut

Tabel 1. Peta Masalah dan Pemecahan

\begin{tabular}{|l|l|l|}
\hline \multicolumn{1}{|c|}{ Permasalahan } & \multicolumn{1}{|c|}{ Akar Masalah } & \multicolumn{1}{c|}{$\begin{array}{c}\text { Pendekatan Pemecahan } \\
\text { Masalah (Solusi) }\end{array}$} \\
\hline $\begin{array}{l}\text { Tidak mengetahui informasi dan } \\
\text { keberadaan Pura Pulaki secara } \\
\text { benar dan tepat }\end{array}$ & $\begin{array}{l}\text { Keterbatasan } \\
\text { pengetahuan (tatwa) } \\
\text { tentang seluk beluk pura }\end{array}$ & $\begin{array}{l}\text { Diberikan informasi memadai } \\
\text { tentang Pura Pulaki }\end{array}$ \\
\hline $\begin{array}{l}\text { Kurang keterampilan berbahasa } \\
\text { asing (Bahasa Inggris) } \\
\text { komunikatif dan fungsional }\end{array}$ & $\begin{array}{l}\text { a. Jarang menggunakan } \\
\text { b. Pernah belajar tetapi } \\
\text { tidak komunikatif dan } \\
\text { fungsional }\end{array}$ & $\begin{array}{l}\text { Pemantapan keterampilan } \\
\text { berbahasa asing (Bahasa } \\
\text { Inggris) komunikatif dan } \\
\text { fungsional }\end{array}$ \\
\hline $\begin{array}{l}\text { Kurang keterampilan Guiding } \\
\text { yang baik dan benar }\end{array}$ & $\begin{array}{l}\text { a. Otodidak } \\
\text { b. Tidak pernah belajar } \\
\text { guiding secara khusus }\end{array}$ & $\begin{array}{l}\text { Pembekalan dan } \\
\text { pendampingan keterampilan } \\
\text { guiding yang baik dan benar }\end{array}$ \\
\hline
\end{tabular}

\section{Hasil dan Pembahasan}

Secara Geografis, kawasan Pura Pulaki, desa Banyupoh, kecamatan Gerokgak terletak di bagian barat Kabupaten Buleleng, sekitar $36 \mathrm{~km}$ dari pusat kota Singaraja. Kawasan Pura Pulaki meliputi Pura Pulaki, Pura Pabean, Pura Kerta Kawat, Pura Melanting, dan Pura Pucak. Pura-pura dimaksud tidak hanya menyimpan misteri sejarah pemerintahan jaman kerajaan masa lampau di wilayah Kabupaten Buleleng pada umumnya, tetapi juga mengandung misteri tentang keberadaan unsur-unsur magis yang dikaitkan dengan mitos dan legenda yang tentu saja mengundang keingintahuan para umat dan wisatawan untuk mengunjungi kawasan ini. Diyakini pula bahwa kawasan pura yang Nyegara Gunung (memiliki letak geografis yang mempertemukan wilayah pegunungan dan laut) ini kaya akan benda-benda suci nan sakral yang sewaktu-waktu bisa diperoleh oleh siapa saja, biasanya berupa batu permata dengan segala bentuk dan kegunaannya. Keberadaan kawasan pura Pulaki dengan segala keunikan fisik dan spiritual di atas merupakan potensi wisata alam dan spiritual yang cukup menjanjikan.

Daerah sebelah selatan wilayah ini ditandai dengan bukit-bukit cadas dengan kawasan hutan vegetasi iklim tropis sedang yang masih asli. Kawasan hutan dihuni oleh 
ratusan kera yang diyakini sebagai penjaga kawasan Pura Pulaki. Wilayah laut membatasi sepanjang garis sisi utara wilayah ini.

Masyarakat di kawasan Pura Pulaki, desa Banyupoh tergolong heterogen, mereka terdiri dari masyarakat lokal dan pendatang. Rasio perbandingan masyarakat lokal dan pendatang rata-rata sebesar 3:1. Budaya masyarakat setempat juga dipengaruhi oleh kebudayaan yang dibawa oleh pendatang yang berasal dari luar kecamatan, kabupaten, bahkan luar Bali yang tinggal dan menetap di sekitar kawasan ini. Beberapa etnis budaya yang ada di sekitar masyarakat lokal meliputi Bali, Jawa, Madura, dan Cina. Hal ini terjadi karena posisi desa Banyupoh di kecamatan Gerokgak sangat dekat dengan Pelabuhan Gilmanuk, yang merupakan pelabuhan penyeberangan Jawa-Bali serta akses jalur laut yang begitu terbuka sepanjang bibir pantai. Pendatang dari luar kabupaten berasal dari beberapa kabupaten meliputi kabupaten Jembrana, Tabanan, Karangasem dan Kodya Denpasar.

Sekitar 81,5\% masyarakat sekitar Pura Pulaki di desa Banyupoh yang beragama Hindu mengandalkan mata pencaharian mereka sebagai petani anggur, peternak, wiraswasta, pedagang di warung atau pasar tradisional, nelayan dan buruh serabutan karena terkendala tingkat pendidikan dan keterampilan yang kurang memadai. Rata-rata pendapatan yang mereka peroleh tidak lebih dari Rp 17.500- Rp 20.000 setiap harinya. Hanya kurang dari $21 \%$ masyarakat berprofesi sebagai pegawai, baik di negeri maupun swasta. Rasio tingkat pendidikan mereka yang meliputi tingkat SD: SMP: SMA/SMK: Perguruan Tinggi sebanyak 52\%: 30\%: 12\%: 6\%. Bahkan ada yang sama sekali tidak pernah sekolah atau putus sekolah di tingkat SD. Secara sosial ekonomi, mereka tergolong masyarakat dengan tingkat sosial ekonomi rata-rata menengah ke bawah.

Kelompok sasaran program adalah pemuda Hindu anggota Sekaha Teruna Teruni Desa Banyupoh, Kecamatan Gerokgak di kawasan Pura Pulaki yang sedang dan atau telah mengenyam pendidikan di tingkat SMP dan SMA/SMK yang masih produktif, berumur 12 s/d 21 tahun. Mereka menjadi kelompok sasaran karena mereka memiliki dasar kemampuan rata-rata cukup untuk menerima materi program pelatihan dan pendampingan yang berupa pengayaan informasi Kawasan Pura Pulaki, keterampilan bahasa Inggris tingkat dasar/madya, dan keterampilan pemandu wisata. Disamping itu, 
mereka juga masih memilki peluang cukup besar untuk mengembangkan karir pada jasa pariwisata dan pemasaran, dalam hal ini produk wisata spiritual.

Jumlah mitra yang diberdayakan sebanyak 40 orang dengan melibatkan 3 orang rekan mahasiswa Jurusan Bahasa Inggris DIII Undiksha yang telah memiliki keterampilan Bahasa Inggris dan pemanduan wisata yang cukup sebagai mitra pendamping. Tempat pelatihan adalah di aula desa Banyupoh yang tepat berada di sebelah kantor desa setempat. Kapasitas aula mencapai kurang lebih 500 orang. Namun pada saat kegiatan pengabdian, peserta berjumlah 40 orang. Tahap awal kegiatan dilaksanakan oleh tim melalui penjajagan awal ke lokasi mitra. Konsultasi dan koordinasi juga dilakukan dengan pihak desa Banyupoh, khususnya dengan bapak perbekel, sekretaris desa, koordinator bidang kesra dan rekan-rekan anggota Sekeha teruna teruni. Rapat-rapat persiapan administrasi dan perencanaan program kegiatan juga dilakukan oleh tim bersama-sama mitra.

Setelah melakukan penjajagan dan koordinasi kepada pihak mitra, tim merencanakan dan menyusun materi kegiatan. Materi kegiatan meliputi pengetahuan umum dan praktis tentang aturan dan tata cara pemanduan wisata, beberapa fungsi dan ekpresi Bahasa Inggris yang sering digunakan di dalam pemanduan wisata, dan informasi tentang Pura Pulaki. Informasi-informasi yang terdapat di dalam materi di peroleh dari internet dan referensi-referensi terkait. Informasi tentang pura juga dimintakan klarifikasi kepada staf desa, pemangku, serta penegemong pura setempat sehingga diperoleh informasi dan data yang sahih atau akurat. Selain penyusunan materi, tim juga melaksanakan pembagian tugas untuk dapat memberikan pelatihan secara sistematis dan efektif sesuai dengan metode pelaksanaaan kegiatan yang telah dirancang. Tiga orang dosen memberikan materi masing-masing tata cara pemanduan wisata, fungsi dan ekspresi Bahasa Inggris, dan Wawasan tentang Pura Pulaki secara bergantian. Selanjutnya tim bersama-sama 3 orang mahasiswa Jurusan Bahasa Inggris DIII memberikan pendampingan kepada peserta pelatihan selama masa pelatihan berlangsung.

Tahapan-tahapan aktivitas secara umum yaitu: penyemaian informasi (encoding), yakni tahap pemantapan pengetahuan konsep tentang keberadaan pura secara filosofis, empiris, dan geografis. Informasi tentang pura diperoleh dari beberapa situs di internet 
dan didiskusikan kebenarannya lebih lanjut dengan pihak aparat desa, pemangku, dan pengempon pura setempat sehingga diperoleh informasi dan data yang akurat mengenai keberadaan pura. Informasi ini selanjutnya dijadikan bahan di dalam pelatihan dimaksud.

Informasi akurat tentang Pura Pulaki juga diberikan kepada peserta pelatihan guna memberikan wawasan dan pengetahuan yang tepat tentang keberadaan pura terkait lokasi, fungsi, struktur, dan sejarah pura dimaksud. Hal ini sangat berguna untuk mereka dalam memberikan penjelasan kepada wisatawan yang ingin mengetahui seluk beluk pura secara detail, benar, dan tepat. Pada awal kegiatan, para peserta memberikan informasi yang bervariasi tentang Pura Pulaki kepada tim panitia. Hal ini mebuktikan bahwa mereka belum memiliki wawasan dan pengetahuan yang sama tentang keberadaan Pura Pulaki. Prosentase pengetahuan peserta tentang Pura Pulaki pada awal kegiatan adalah 56\%. Ini menunjukkan prosentase yang cukup, namun beberapa informasi tentang Pura Pulaki yang sebelumnya salah perlu diluruskan guna memantapkan pengetahuan peserta tentang Pura Pulaki. Materi terkait keberadaan pura, yang sebelumnya telah mengalami penyesuaian dan pendalaman berdasarkan informasi pihak desa; pemangku; dan pangemong pura, kemudian dibagikan kepada setiap peserta.

Selain itu, keterampilan pemanduan dengan bahasa asing, khususnya Bahasa Inggris dilatihkan dengan memberikan beberapa informasi praktis tentang jasa pemanduan guna memberikan wawasan tentang aturan dan tata cara pemanduan yang baik. Pemberian materi terkait disampaikan oleh ketua tim. Pembekalan diawali dengan menayangkan 3 buah video berisikan pemanduan wisata di Bali yang dilakukan oleh 2 orang asing, penutur asli Bahasa Inggris, dan 1 orang lokal Bali yang masing-masing berdurasi 7-8 menit. Kemudian peserta diminta untuk mendengarkan intisari informasi yang ada di dalam video, termasuk komponen-komponen penting yang perlu disampaikan ketika memberikan pemanduan wisata tentang tempat, acara, budaya tertentu. Kesempatan diskusi kemudian dibuka untuk menampung beberapa pertanyaan peserta pelatihan. Secara umum mereka mampu memahami inti informasi yang disampaikan di dalam 3 video yang ditayangkan.. setelah sesi diskusi, para pemandu lokal kawasan Pura Pulaki pada kesempatan itu juga diberikan waktu untuk 
menyampaikan pengalaman mereka dalam guiding yang dapat memberikan gambaran nyata tentang pemanduan wisata khususnya wisata spiritual atau Spiritual Tour Guide di kawasan Pura Pulaki kepada rekan-rekan mereka. Dari penjelasan mereka, ada tiga hal yang disampaikan yakni pramuwisata harus memilki informasi lengkap tentang objek wisata, memiliki keterampilan bahasa yang memadai dan fungsional (dimengerti oleh kedua belah pihak walaupun terkadang struktur kalimat tidak sesuai dengan kaidah bahasa target), dan mampu mengetahui karakteristik wisman yang dipandu secara tepat yang nantinya berpengaruh pada teknis dan jenis pelayanan yang diberikan kepada mereka.

Informasi tata cara pemanduan wisata ini penting diberikan kepada mitra karena sebelum menjadi seorang pemandu wisata, mereka seharusnya mengetahui beberapa tata cara yang baik dan benar untuk menjadi seorang pemandu wisata, khususnya pengetahuan tentang etika memandu wisatawan. Pembekalan tentang materi pemandu wisata juga menimbulkan kesadaran peserta pelatihan tentang peran penting jasa pemandu wisata dalam memberikan informasi yang tepat dan benar tentang suatu kawasan wisata, memasarkan potensi-potensi wisata yang ada di daerah mereka selain wisata spiritual, dan menjaga kelestarian dan kesakralan kawasan wisata terkait karena mereka memperoleh manfaat, khususnya manfaat ekonomi, dengan menjaga kelestarian situs pura, budaya, maupun potensi-potensi lainnya. Informasi pemandu wisata juga menggugah sebagian besar peserta untuk mencoba menekuni bisnis jasa pemandu wisata di kawasan wisata spiritual Pura Pulaki. Hal ini berarti bahwa, pembekalan pengetahuan dan informasi terkait telah dapat memberikan potensi alternatif usaha kepada peserta yang pada saat pelaksanaaan program berprofesi sebagai buruh, petani, nelayan, pedagang batu bertuah, dan distributor pangan. Rekan-rekan yang telah menekuni jasa pemanduan wisata juga memperoleh wawasan tentang tata cara yang benar dan etika terkait sehingga nantinya mereka mampu memberikan pelayanan terbaik kepada wisman yang memerlukan informasi dan arahan dari mereka.

Informasi praktis tentang beberapa fungsi dan ekpresi Bahasa Inggris yang sering digunakan dalam berkomunikasi dengan wisman oleh para pemandu wisata juga diberikan kepada peserta pelatihan. Fungsi dan ekspresi bahasa yang dilatihkan meliputi: menyapa, memperkenalkan diri, bertanya, menawarkan bantuan, dan 
menjelaskan. Fungsi dan ekspresi bahasa Inggris perlu diberikan karena bahasa adalah media utama yang digunakan dalam berkomunikasi (bertanya dan memberikan penjelasan) dengan wisatawan manca negara selama pemanduan wisata berlangsung. Pada saat awal pelatihan, pengetahuan dan keterampilan mereka tentang fungsi dan ekspresi Bahasa Inggris hanya 35\%. Pengetahuan ini hanya dimiliki oleh $60 \%$ peserta; rekan-rekan guide lokal memiliki pengetahuan $80 \%$ dan keterampilan menggunakan 75\% karena mereka sudah terbiasa menggunakannya di lapangan, dan sisa $40 \%$ menguasai Bahasa Inggris dalam kosakata terkait pariwisata yang masih terbatas. Pada awal kegiatan secara umum, kelemahan peserta terletak pada penguasaan kosakata terkait pariwisata $35 \%$, ketepatan struktur bahasa $30 \%$; pengucapan kata dan intonasi $40 \%$, dan kelancaran berbahasa $40 \%$.

Kegiatan selanjutnya adalah pengintegrasian informasi menjadi suatu pemahaman (decoding), yakni penggabungan pengetahuan dasar, pengetahuan tambahan mereka tentang Pura Pulaki, dan keterampilan penyampaian informasi kepada wisatawan dalam Bahasa Inggris. Pada tahap ini mereka diberikan kesempatan untuk berdiskusi dengan sesama peserta pelatihan termasuk dengan para instruktur. Peserta pelatihan diberikan waktu masing-masing 7-8 menit untuk berdiskusi tentang 3 kelompok materi yang telah mereka peroleh. Setiap 7-8 menit kelompok mereka diwajibkan untuk menjawab pertanyaan dan atau memperagakan/ melatihkan beberapa instruksi langsung tentang materi-materi terkait. Dengan cara ini, tim mengidentifikasi tingkat pemahaman peserta tentang materi yang telah disampaikan. Pada tahap ini, 67\% pertanyaan terkait informasi tentang guiding dan Pura Pulaki dapat dijawab oleh peserta, dan 60\% instruksi tentang guiding dan penggunaan fungsi dan ekspresi Bahasa Inggris bisa diperagakan dengan baik dan tepat.

Tahap dilanjutkan dengan perekaman informasi (storing), yakni pemberian kesempatan kepada mitra untuk merekam informasi yang telah diintegrasikan selama beberapa waktu tertentu (dalam waktu sekitar 20-30 menit) sesuai dengan kemampuan mereka dan melatihkan keterampilan guiding dan Bahasa Inggris. Pada tahap ini mereka di dalam kelompok, didampingi oleh 1 orang instruktur, secara bergantian bertanya dan menjawab/ menjelaskan informasi sederhana tentang Pura Pulaki. Kegiatan ini juga memberikan penguatan atau drilling informasi dan keterampilan berbahasa kepada para 
peserta. Semakin sering dan lama mereka melatihkan ini di dalam kelompok mereka, semakin intensif pembelajaran yang mereka lakukan sehingga semakin kuat ekspos informasi dan pengalaman yang mereka peroleh dari kegiatan dimaksud. Pada gilirannya, penguatan informasi dan pengalaman ke dalam memori mereka semakin kuat. Pada tahap ini, keterampilan peserta untuk melakukan guiding tergolong cukup (61\%). Kemampuan pemberian informasi tentang Pura Pulaki cukup (69,5\%). Permasalahan yang masih ada meliputi ketidakmampuan peserta dalam menyampaikan sejarah Pura Pulaki terutama terkait peran kawasan Pulaki di masa lalu, tahun peristiwaperistiwa penting terkait, dan masa pemerintahan sejalan perubahan lokasi dan struktur pura. Sedangkan keterampilan penggunaan Bahasa Inggris juga tergolong cukup (60,5\%). Permasalahan masih cukup banyak muncul pada penguasaan kosakata, struktur bahasa, dan pengucapan kata, termasuk kelancaran penggunaan Bahasa Inggris.

Pelatihan kemudian dilanjutkan dengan simulasi (rehearsal), yakni pelatihan dan pendampingan terhadap mitra dalam menguji cobakan apa yang telah mereka terima dan pahami sebelumnya. Mereka diminta untuk bertanya dan memberikan informasi terkait Pura Pulaki dalam Bahasa Inggris melalui permainan peran (Role play), sebagian berperan sebagai wisman dan sisanya berperan sebagai pemandu wisata. Kemudian mereka bertukar peran. Prosedur pelaksanaanya sama dengan tahap sebelumnya namun mereka diminta secara berkelompok memperagakan keterampilan guiding di depan lokasi pelatihan dan ditonton oleh kelompok peserta lainnya. Dengan cara ini, antar individu dan kelompok dapat berbagi pengetahuan, keterampilan, pengalaman belajar dan berlatih. Disamping itu, mereka juga dapat melihat kelebihan dan kekurangan masing-masing individu dan kelompok untuk dijadikan refleksi demi perbaikan. Pada tahap ini, keterampilan peserta untuk melakukan guiding masih tergolong cukup (64,6\%) dan kemampuan menjelaskan keberadaan Pura Pulaki cukup (71,3\%). Sejarah dan seluk-beluk pura masih cukup sulit untuk dipahami oleh peserta sedangkan fungsi kawasan Pulaki di masa lalu dan sekarang sudah bisa dijelaskan dengan baik. Sementara itu, keterampilan berbahasa Inggris peserta tergolong cukup (67,5\%). Mereka masih bermasalah pada penguasaan kosakata, struktur bahasa, dan pengucapan kata yang sebagian besar sangat berbeda dengan tulisannya. Tingkat kelancaran berbahasa Inggris juga masih perlu dilatih dan ditingkatkan. 
Tahap akhir adalah pembelajaran informasi (learning), yakni pemberian penguatanpenguatan dan konfirmasi terhadap pengetahuan dan keterampilan yang telah mereka terima dan uji cobakan. Pada tahap ini mereka diberi masukkan atau umpan balik terkait dengan beberapa hal yang sudah mereka lakukan dengan baik dan hal-hal yang masih dianggap perlu diperbaiki di masa yang akan datang. Tahap ini dilakukan secara informal guna menjaga kedekatan tim dengan mitra secara personal dan emosional. Tahap ini juga merupakan tahap pendampingan yang diberikan guna memantapkan pengetahuan dan pelatihan mereka.

Secara umum, pengetahuan dan keterampilan Spiritual Tour Guide mitra tentang Pura Pulaki cukup dengan nilai rata-rata 67,8\%. Kesan yang diberikan sangat baik. Hal ini terbukti dengan tingginya antusiasme warga desa, pemuda Desa Banyupoh, dalam mengikuti kegiatan pelatihan dilaksanakan. Bantuan dalam penyediaan sarana upacara terkait pelaksanaan pelatihan, dan berbagai jenis pertanyaan oleh mitra terkait materi dan keterampilan yang diberikan menunjukkan perhatian mereka yang cukup baik dan antusiame terhadap program yang dijalankan. Disamping itu pula, kepala desa dan peserta secara langsung memohon kepada Tim LPM Undiksha untuk memberikan pelatihan selanjutnya jika melaksanakan program P2M terkait. Secara khusus juga Bapak Kepala Desa memohon kesediaan tim untuk membantu menyusun konsep proposal kegiatan untuk diajukan kepada pemerintah daerah guna menunjang pelaksanaan kegiatan yang sama di desa Banyupoh untuk periode selanjutnya. Tim telah membantu penyiapan proposal dimaksud dan telah menyampaikannya langsung kepada Bapak Kepala Desa sehari setelah kegiatan pembukaan P2M berlangsung untuk segera ditindaklanjuti atau diajukan kepada pihak terkait di bawah Pemerintah Tingkat II Kabupaten Buleleng.

\section{Penutup}

Berdasarkan paparan di atas, program Pemberdayaan Masyarakat melalui Pelatihan Spiritual Tour Guide di Kawasan Pura Pulaki telah memberikan pengalaman peserta pelatihan dalam memandu wisata spiritual, menggunakan Bahasa Inggris aktif dan fungsional dalam memandu wisata spiritual, dan memberikan pengetahuan dan wawasan yang memadai tentang keberadaan Pura Pulaki. Program juga telah 
memberikan keterampilan pemanduan wisata spiritual peserta pelatihan dengan rata-rata kemampuan cukup.

\section{DAFTAR PUSTAKA}

Nitiasih, Putu Kerti, Putu Eka Dambayana Suputra, I Nyoman Adijaya Putra, dan Ni Nyoman Padmadewi. 2010. Pelatihan "Spiritual Tour Guide" bagi Mahasiswa Jurusan Agama Hindu STKIP Singaraja. Laporan P2M Undiksha. Tidak dipublikasikan.

Suputra, Putu Eka Dambayana, Putu Kerti Nitiasih, I Nyoman Adijaya Putra, dan Ni Nyoman Padmadewi. 2011. IbM Spiritual Tour Guide: Pelatihan "Spiritual Tour Guide" bagi Mahasiswa Jurusan Agama Hindu STKIP Singaraja. Laporan P2M Undiksha 